\title{
Our Experience in Neonatal Acupressure and Acupuncture
}

\author{
Aslıhan Abbasoğlu', Mehmet Tuğrul Cabığlu' ${ }^{2}$ \\ ${ }^{1}$ Department of Neonatology, Gaziantep Children Hospital, Gaziantep, Turkey \\ ${ }^{2}$ Department of Physiology, Başkent University Faculty of Medicine, Ankara, Turkey \\ Email:tugcab@gmail.com
}

Received 6 January 2016; accepted 22 January 2016; published 25 January 2016

Copyright (C) 2016 by authors and OALib.

This work is licensed under the Creative Commons Attribution International License (CC BY). http://creativecommons.org/licenses/by/4.0/

\section{(c) (i) Open Access}

\begin{abstract}
We want to share our experience about acupuncture and acupressure in newborns as a treatment modality. Researches have shown that acupressure and acupuncture are effective for headaches, stress control or obesity. Our studies and experiences about acupressure and acupuncture use in newborns and adults suggest that alternative and complementary medicine could be a promising treatment modality to be used with modern medicine. We studied in which diseases and how we can use these treatment modalities in newborns. We summarised our studies about acupuncture and acupressure effect for minor painful procedures and skin perfusion and thought that this could be a new treatment modality. Further research is needed to evaluate effective modes and doses for pain control in newborns.
\end{abstract}

\section{Keywords}

Pain, Newborn, Acupuncture, Acupressure

Subject Areas: Internal Medicine

\section{Introduction}

Health is a whole state of physical, psychological and social well-being. In newborn care, supporting the mother and her baby by the ancient healing knowledge can be combined with modern medical care. In this regard, the mostly studied and practiced method is the kangaroo care. The other few subjects recently studied are massage therapy, therapeutic touch, acupuncture, and acupressure.

Healthy term newborns during routine follow-up visits commonly undergo painful procedures whereas preterm infants having the same during their neonatal intensive care unit stay. Some research suggests that painful experiences can alter clinical outcome and brain development in these infants [1] [2].

Nonpharmacological strategies are important for managing neonatal pain because pharmacologic analgesic agents tend to have low efficacy and have potential side effects in this age group [3]-[5]. 
The two most widely studied non-pharmacological methods are sucrose administration and non-nutritivesucking [3]. The American Academy of Pediatrics and the Canadian Paediatric Society recommend oral administration of 0.05 to $0.5 \mathrm{~mL}$ of $24 \%$ sucrose 1 to 2 minutes before the procedure to decrease neonatal pain [3].

Acupressure is a pain-relieving method; the fingers are used to press key acupuncture points on the skin surface that stimulates the body's regulatory processes [6].

Acupuncture is an ancient technique is based on the theories of Traditional Chinese Medicine which involves stimulating "acupoints" via insertion of thin needles or via laser [7].

Light needle acupuncture has been used to show the effect on feeding, stooling and sleeping in infants with infantile colic and to show analgesic effects on procedural pain in preterm infants [8]. The efficacy and safety of pediatric light needle acupuncture has been investigated, and reviews to date have concluded that acupuncture use should be limited to clinical trials [9] [10].

To date acupressure and acupuncture, including needle and laser acupuncture have been used for pain, skin perfusion, weight gain, neonatal abstience syndrome, agitation and hypoxic ischemic encephalopathy. We studied needle acupuncture, laser acupuncture and acupressure for minor painful procedures.

\section{Materials and Methods}

Ecevit et al. [11] studied 10 preterm infants who required a heel prick for blood gas analysis. In this study, needle acupuncture was performed at Yintang point before heel prick. They observed shorter crying duration and lower (better) neonatal infant pain scores in their needle acupuncture group compared to untreated controls. It has been reported that the levels of enkephalin, endomorphin-1, beta-endorphin, and serotonin increase in plasma and brain tissue after acupuncture or electroacupuncture application. When an acupuncture needle is inserted, it stimulates pain receptors (nevre endings) and causes the secretion of endogenous opioids, which play a role in pain control [12].

Abbasoglu et al. [13] found that applying acupressure at the BL60 and K3 points before heel lancing was safe and associated with shorter procedural time and shorter duration of crying in preterm infants. Acupressure stimulates peripheral sensory nerve endings and causes the release of vasoactive neuropeptides, such as calcitonin gene-related peptide and substance P. [14]. These mediators induce local vasodilation, thus increasing skin blood flow. Distinct from seratonin effects, increased blood supply around the malleolus as a result of acupressure might also have contributed to the shorter procedure time we observed in the acupressure group.

Abbasoglu et al. [15] indicated that laser acupuncture (LA) with 1.125 microjoules of energy at the Yintang point two minutes prior to heel lancing is less effective than oral sucrose for reducing the discomfort of this procedure. We found shorter procedure time in the LA group compared to the oral sucrose group, but longer crying time and worse NIPS scores in the LA group. We observed shorter heel-lancing procedure time in healthy term infants who received LA compared to their counterparts who received oral sucrose. Part of the explanation for this may be the vasomodulatory effect of LA on endothelium and vascular smooth muscle [16].

Tugcu et al. [17] showed the impact of acupressure application on the Yintang point on neonatal skin perfusion, oxygen saturation and pulse rate. In this study, it was found that after acupressure application on the Yintang point, the pulse rate value in newborns decreased significantly. In our opinion, this decrease occurs also as a result of the fact that acupressure application on the Yintang point decreases sympathetic activity. The study done by Arai YC et al. also demonstrated that acupressure application on the Yintang point significantly decreases sympathetic activity [18].

\begin{tabular}{|c|c|c|c|c|}
\hline Study & Study population & Comparision & Primary outcome & Acupuncture point \\
\hline Ecevit et al. & Preterm infants $(\mathrm{n}=10)$ & $\begin{array}{l}\text { Breast milk only and } \\
\text { breast milk and needle } \\
\text { acupuncture }\end{array}$ & $\begin{array}{l}\text { Crying duration during heel prick } \\
\text { for blood gas analysis }\end{array}$ & Yintang point \\
\hline Abbasoglu et al. & Preterm infants $(\mathrm{n}=36)$ & $\begin{array}{l}\text { Acupressure and } \\
\text { routine care }\end{array}$ & $\begin{array}{l}\text { Shorter procedural time and shorter } \\
\text { crying time }\end{array}$ & BL60 and K3 points \\
\hline Abbasoglu et al. & Term infants $(n=42)$ & $\begin{array}{l}\text { Laser acupuncture and } \\
\text { oral sucrose solution }\end{array}$ & $\begin{array}{l}\text { Shorter procedure time and longer } \\
\text { crying time and worse NIPS scores }\end{array}$ & Yintang point \\
\hline Tugcu et al. & $\begin{array}{l}\text { Term infants } \\
\quad(\mathrm{n}=17)\end{array}$ & Acupressure & $\begin{array}{l}\text { Neonatal skin perfusion, oxygen } \\
\text { saturation and pulse rate. }\end{array}$ & Yintang point \\
\hline
\end{tabular}




\section{Conclusion}

Acupressure and acupuncture has the potential to decrease neonatal exposure to potentially neurotoxic analgesic and sedative agents during their early life. In newborn care, traditional and complementary medicine could be combined with modern medical care. The results of our studies suggest using acupressure and acupuncture for minor painful procedures in newborn infants could be a simple, quick and safe way. Further studies would be helpful for practice of new points and modes to use in acupressure an acupuncture for pain control in newborns.

\section{References}

[1] Anand, K.J. and Scalzo, F.M. (2000) Can Adverse Neonatal Experience Alter Brain Development and Subsequent Behavior? Biology of the Neonate, 77, 69-82. http://dx.doi.org/10.1159/000014197

[2] Grunau, R.E., Oberlander, T.F., Whitfield, M.F., Fitzgerald, C. and Lee, S.K. (2001) Demographic and Therapeutic Determinants of Pain Reactivity in Very Low Birth Weight Neonates at 32 Weeks' Postconceptional Age. Pediatrics, 107, 105-112. http://dx.doi.org/10.1542/peds.107.1.105

[3] American Academy of Pediatrics Committee on Fetus and Newborn, American Academy of Pediatrics Section on Surgery, Canadian Paediatric Society Fetus and Newborn Committee, Batton, D.G., Barrington, K.J. and Wallman, C. (2006) Prevention and Management of Pain in the Neonate: An Update. Pediatrics, 118, 2231-2241.

[4] Axelin, A., Salanterä, S., Kirjavainen, J., et al. (2009) Oral Glucose and Parental Holding Preferable to Opioid in Pain Management in Preterm Infants. Clinical Journal of Pain, 25, 138-145. http://dx.doi.org/10.1097/AJP.0b013e318181ad81

[5] Carbajal, R., Lenclen, R., Jugie, M., et al. (2005) Morphine Does Not Provide Adequate Analgesia for Acute Procedural Pain among Preterm Neonates. Pediatrics, 115, 1494-1500. http://dx.doi.org/10.1542/peds.2004-1425

[6] Goel, S. (1999) Acupressure Guide. The Principles of Acupressure Technique, Diamond Books, London, 17-54.

[7] Flaws, R. (1993) Traditional Chinese Medicine. In: Burton Goldberg Group, Ed., Alternative Medicine: The Definitive Guide, Future Medicine Publishing, Fife, 450-456.

[8] Landgren, K., Kvorning, N. and Hallström, I. (2011) Feeding, Stooling and Sleeping Patterns in Infants with Colic-A Randomized Controlled Trial of Minimal Acupuncture. BMC Complementary and Alternative Medicine, 11, 93. http://dx.doi.org/10.1186/1472-6882-11-93

[9] Raith, W., Urlesberger, B. and Schmölzer, G.M. (2013) Efficacy and Safety of Acupuncture in Preterm and Term İnfants. Evidence-Based Complementary and Alternative Medicine, 2013, Article ID: 739414. http://dx.doi.org/10.1155/2013/739414

[10] Adams, D., Cheng, F., Jou, H., Aung, S., Yasui, Y. and Vohra, S. (2011) The Safety of Pediatric Acupuncture: A Systematic Review. Pediatrics, 128, e1575-e1587.

[11] Ecevit, A., Ince, D.A., Tarcan, A., Cabioglu, M.T. and Kurt, A. (2011) Acupuncture in Preterm Babies during Minor Painful Procedures. Journal of Traditional Chinese Medicine, 31, 308-310. http://dx.doi.org/10.1016/S0254-6272(12)60009-0

[12] Cabioglu, M.T. and Ergene, N. (2006) Changes in Serum Leptin and Beta Endorphin Levels with Weightloss by Electroacupuncture and Diet Restriction in Obesity Treatment. American Journal of Chinese Medicine, 34, 1-11. http://dx.doi.org/10.1142/S0192415X06003588

[13] Abbasoğlu, A., Cabığlu, M.T., Tuğcu, A.U., İnce, D.A., Tekindal, M.A., Ecevit, A. and Tarcan, A. (2015) Acupressure at BL60 and K3 Points Before Heel Lancing in Preterm Infants. Explore (NY), 11, 363-366. http://dx.doi.org/10.1016/j.explore.2015.07.005

[14] Loaiza, L.A., Yamaguchi, S., Ito, M., et al. (2002) Vasodilatation of Microvessels Induced by Somatic Afferent Stimulation Is Mediated by Calcitonin Gene-Related Peptide Release in the Rat. Neuroscience Letters, 333, 136-140. http://dx.doi.org/10.1016/s0304-3940(02)01030-3

[15] Abbasoğlu, A., Cabığlu, M.T., Tuğcu, A.U., Yapakci, E., Tekindal, M.A. and Tarcan, A. Laser Acupuncture Prior to Heel Lancing for Pain Management in Healthy Term Newborns: A Randomised Controlled Trial. Acupuncture in Medicine.

[16] Lundeberg, T. (2013) Acupuncture Mechanisms in Tissue Healing: Contribution of NO and CGRP. Acupuncture in Medicine, 31, 7-8. http://dx.doi.org/10.1136/acupmed-2013-010313

[17] Tuğcu, A.U., Cabığlu, M.T., Abbasoğlu, A., Ecevit, A., İnce, D.A. and Tarcan, A. Evaluation of Peripheral Perfusion in Term Newborns before and after Yintang Massage. Journal of Traditional Chinese Medicine. 
[18] Arai, Y.C., Ushida, T., Osuga, T., Matsubara, T., Oshima, K., Kawaguchi, K., Kuwabara, C., Nakao, S., Hara, A., Furuta, C., Aida, E., Ra, S., Takagi, Y. and Watakabe, K. (2008) The Effect of Acupressure at Theextra 1 Point on Subjective and Autonomic Responses to Needle İnsertion. Anesthesia \& Analgesia, 107, 661-664.

http://dx.doi.org/10.1213/ane.0b013e31817b8495 